\title{
The Effect of a Balanced Diet Containing Yellow Lupin (Lupinus Luteus L.) on Carcass and Meat Quality of Broiler Ducks
}

Original Article

EAuthor(s)

\section{Biesek J' (iD https://orcid.org/0000-0003-3050-8617 Kuźniacka J! (D) https://orcid.org/0000-0002-0464-0326}

Department of Animal Breeding, Faculty of Anima Breeding and Biology, UTP - University of Science and Technology in Bydgoszcz, Mazowiecka 28, 85-084 Bydgoszcz, Poland.

\section{Mail Address}

Corresponding author e-mail address Jakub Biesek

Department of Animal Breeding, Faculty of Animal Breeding and Biology, UTP

- University of Science and Technology in Bydgoszcz, Mazowiecka 28, 85-084

Bydgoszcz, Poland.

Phone: (+48) 608-509-997

Email: jakub.biesek@utp.edu.pl

\section{- Keywords}

Duck, body weight, carcass, colour, quality water-holding capacity, yellow lupin

\section{ABSTRACT}

The aim of this study was to compare the final productivity parameters, carcass and meat quality in ducks fed with yellow lupin (Lupinus luteus) as a protein source instead of soybean meal. 200 Cherry Valley ducks were divided into two equal groups. Control (1) was fed with soybean meal, experimental (2) was fed with yellow lupin. Productivity parameters were calculated. After 8 weeks of rearing, 10 ducks from each group were slaughtered. The $\mathrm{pH}$ of breast muscles was measured 15 minutes and 24 hours post-mortem. Carcasses were dissected and each carcass part was weighed. After dissection, breast and leg muscles were analysed for selected parameters of meat quality (water holding capacity, and colour). Additionally, drip loss in breasts was analysed. The body weight of ducks, as well as FI and FCR between groups was compared $(p<0.05)$. There were no differences ( $p>0.05$ ) between groups in post-slaughter parameters, but the weight of offal was higher $(p<0.05)$ in group 1 than in group 2. There were no differences in the weight of carcass muscles and fatness between the two groups $(p>0.05)$. Lightness $\left(L^{*}\right)$ and yellowness $\left(b^{*}\right)$ of breast muscles were higher $(p<0.05)$ in group 2 than in group 1 . The water-holding capacity of leg muscles was higher $(p<0.05)$ in group 1 than in group 2. Yellow lupin in duck feed as a high-protein component did not deteriorate most meat traits, or the physicochemical parameters of their muscles. It can be proposed as a partial alternative to soybean meal.

\section{INTRODUCTION}

The worldwide production of duck meat relies on crossbred hybrids. In Poland these are mainly foreign hybrids - French Pekin duck (Grimaud Fréres Sélection), English Pekin duck (Cherry Valley), and crossbreeds of French Muscovy ducks. There are also Polish crossbreeds of Pekin ducks. An increased interest of consumers in duck meat has been observed in many countries. Duck meat is characterized by a darker red colour and higher content of fat compared to chicken or turkey meat. The high nutritional value of duck meat results from the beneficial composition of fatty acids, lipids in muscles, and fat storage (Biesiada-Drzazga et al., 2011; Kokoszyński et al., 2015; Smith et al., 2015).

Meat characteristics, quality of carcass, and parameters of duck meat depend on a number of factors, including origin (genotype), age and sex of birds, management system and diet (Mazanowski et al., 2003; Wołoszyn et al., 2011a, 2011b; Rahman et al., 2014; Smith et al., 2015). Meat traits also depend on how the birds are fed during the rearing period and handled before and during slaughter, and the duration and conditions of meat storage (Ali et al., 2008; Nurkhoeriyati et al., 2012; Zdanowska-Sąsiadek et al., 2013; Naveen et al., 2016). Diet is one of the crucial factors influencing the quality of carcass and meat. The proportion of nutrients in the feed, necessary for proper growth 
and development, especially proteins, must be at an optimal level (Kuźniacka et al., 2014; Świątkiewicz et al., 2017).

Polish regulations prohibiting the distribution of feed originating from genetically modified plants prompted many researchers to investigate sources of protein alternative to soybean, e.g. legumes (lupin species, pea, field bean), that can be grown on different types of soil.

In the past, lupin seeds characterized by high content of antinutrients, like alkaloids or nonstarch polysaccharides, and its level depends on the cultivars and conditions where it is growing. (Hejdysz et al., 2016). It could affect with a negative growth performance, but nowadays the new cultivars of lupins are characterized by lower alkaloid content (Rutkowski et al., 2017). As Hejdysz et al., (2018) reported, the main problem was that many countries don't grow soybean, because of environmental conditions. Yellow lupin seeds have a potential. There is similar content of protein and its utilization is the same as that of soybean. In the other study, ducks were fed with lupinrich feed (Kuźniacka et al., 2020). Authors concluded that the use of yellow lupin seeds with addition of rapeseed meal provided the best results in ducks comparing to the ducks fed with soybean meal. In this research, authors also reported that yellow lupin, cv. Mister in ground form had over $42 \%$ of crude protein in dry matter, no starch was found, as well as the total alkaloids content was very low $(0.00085 \mathrm{~g} / \mathrm{kg}$ in dry matter). Jamroz \& Kubizna (2007; 2008) concluded that 5 to $15 \%$ of lupin seeds could be proposed in waterfowl diets. Biesek et al., (2020) also suggested that the use of yellow lupin-rich feed in the waterfowl (geese) diets could be proposed as an alternative for soybean meal.

The aim of our study was to compare the quality of carcass and meat from ducks receiving a balanced feed containing 38\% yellow lupin (Lupinus luteus L.) as a source of protein alternative to commonly used soybean meal.

\section{MATERIALS AND METHODS}

According to the directive no. 2010/63/EU, the agreement of Local Ethics Committee was not required.

\section{Animals and diets}

One-day-old Cherry Valley SM3 Medium broiler ducks (males and females) were kept in pens on litter in two groups, 100 birds each. The sex breakdown was not included because sexual dimorphism does not differentiate in slaughter ducks. The control group (1) received balanced feed containing soybean meal (SBM). The experimental group (2) received balanced feed containing yellow lupin var. Mister (ground form). Ducks were raised in production conditions on a small-scale farm. In the duck house there were 4 pens, where 50 birds were kept in each. (2 pens $=100$ birds $=1$ group). Each duck was marked by padlock stamp, so each bird was treated as the experimental unit. The experiment was of implementation nature. The experimental tests were provided earlier in the experimental station (Kuźniacka et al., 2020). This part was practical test, which improved that small-scale production of broiler ducks could be done with the use of yellow lupin seeds as an alternative source of plant protein for commonly used soybean meal. The main assumption of the project was cooperation with small producers, where they expressed their willingness to provide production buildings without much interference in order to create conditions prevailing as in experimental (sterile) stations. The feed provided to both groups contained 55\% of concentrate and $45 \%$ of wheat in the whole rearing period. The composition of feed and concentrates is presented in Table 1. Total crude protein content was declared at $19.50 \%$ and metabolic energy of around $11.95 \mathrm{MJ}$ in $\mathrm{kg}$ of feed for both groups. Birds received feed and water ad libitum and were reared for 8 weeks.

Table 1 - Composition of feed for ducks.

\begin{tabular}{|c|c|c|}
\hline Composition of feed, \% & 11) & $2^{2)}$ \\
\hline Concentrate & 55 & 55 \\
\hline Wheat & 45 & 45 \\
\hline Composition of concentrate, $\%$ & $1^{1)}$ & $2^{2)}$ \\
\hline SBM $44 \%$ & 65 & - \\
\hline Yellow lupin var. Mister & - & 68.98 \\
\hline Potato protein & - & 3 \\
\hline Brewer's yeast & - & 3 \\
\hline Triticale in concentrate & 23.04 & 12 \\
\hline Soybean oil & 5.2 & 5.4 \\
\hline Premix $1 \%$ & 2 & 2 \\
\hline Fodder chalk & 2 & 2 \\
\hline Monocalcium phosphate & 1.52 & 1.74 \\
\hline $\mathrm{NaHCO} 3$ & 0.84 & 0.8 \\
\hline Fodder salt & 0.18 & 0.12 \\
\hline L-lysine & - & 0.32 \\
\hline DL - methionine & 0.2 & 0.4 \\
\hline L-threonine & 0.02 & 0.24 \\
\hline
\end{tabular}




\section{Productivity parameters}

Productivity parameters were calculated for the whole flock (100 birds per group that was 50 birds in each of 2 pens). Ducks and feed were weighted. On this basis the mean parameters of initial and final body weight (BW), body weight gain (BWG), feed intake (FI) and feed conversion ratio (FCR) per $\mathrm{kg}$ of body weight gain were calculated. After 8 weeks of rearing, 20 birds (10 from each group), of body weight close to the mean for the whole flock, were slaughtered. From each group 5 females and 5 males were selected for carcass and meat quality analysis. Plucked and gutted carcasses were analysed in a laboratory for qualitative parameters.

\section{Meat quality}

Carcass traits and meat quality analyses were done for 20 birds (10 from each group), which were selected for slaughter like a representative bird for research (each bird had a padlock stamp). The $\mathrm{pH}$ value of breast muscles was measured 15 minutes post-mortem $\left(\mathrm{pH}_{15}\right)$. The carcasses were refrigerated at $2^{\circ} \mathrm{C}$ for 24 hours and $\mathrm{pH}$ was measured again $\left(\mathrm{pH}_{24}\right)$ using a CX-701 El-metron $\mathrm{pH}$ meter with a knife electrode. Duck carcasses were weighed on RADWAG scales with accuracy to the nearest 0.01 $g$ and then dissected using the method described by Ziołecki \& Doruchowski (1989). The following parts were separated: breast muscles, leg muscles, skin with subcutaneous fat from the whole carcass, including breast and leg parts, abdominal fat, offal (liver, heart, stomach), wings with skin, neck with skin, and carcass remains (body and leg bones). Each carcass part was weighed. The colour of breast and leg muscles was assessed using a colorimeter (Konica Minolta, model CR400, Japan). The apparatus was calibrated using the white calibration plate no. 21033065 and

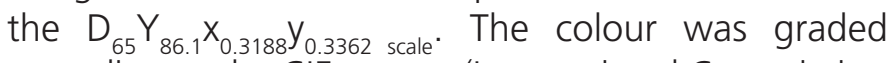
according to the CIE system (International Commission on Illumination) for L* (lightness), a* (redness), and b* (yellowness) (CIE, 1986). To analyse drip loss, breast muscles were weighed post-mortem (M1) and after 24-hour storage at $2^{\circ} \mathrm{C}(\mathrm{M} 2)$ (Honikel, 1987). Breast and leg muscles were also analysed for water holding capacity using a modified method proposed by Grau and Hamm (1952). For that purpose, pooled samples (about $0.300 \mathrm{~g}$ ) of disintegrated muscles were wrapped in Whatman grade 1 filter paper and kept under $2 \mathrm{~kg}$ pressure for 5 minutes. The water holding capacity of meat was calculated based on the difference in weight before and after the test.

\section{Statistical analysis}

Numerical data were analysed using statistical software Statistica 10.0 PL (2011) by calculating means and their standard deviations $( \pm$ SD) using one-way analysis of variance (ANOVA). The standard error of measurement (SEM) was also calculated. The significance of differences was verified by the post-hoc Sheffe test. The level of significance was at $p<0.05$. The individual bird (marked by padlock stamp) was the experimental unit for all the analysed traits of carcass and meat quality. This work focused on quality analyses. Information about the productivity parameters are additional part. It was not typical nutrition experiment, but poultry product quality research.

\section{RESULTS}

\section{Productivity parameters}

Production results of whole flock kept in the experiment (100 birds per group) have been calculated. In the group fed with feed based on soybean meal (1), the initial body weight was $52.89 \mathrm{~g}$, and in the experimental group $53.45 \mathrm{~g}$. The final body weight $(3117.90 \mathrm{~g})$ was shown to be $37.7 \mathrm{~g}$ higher in experimental group (2) than in the group of ducks fed with feed based on soybean meal (3080.20 g). Daily weight gain (BWG) was also higher in group 2 ( $54.06 \mathrm{~g} /$ day) by $0.68 \mathrm{~g}$ than in group 1 ( $54.72 \mathrm{~g} /$ day). Lower feed intake (FI) and feed conversion ratio (FCR) were demonstrated in group $1(9.07 \mathrm{~kg}, 2.94 \mathrm{~kg}$ per $\mathrm{kg}$ gain, respectively) than in group $2(9.26 \mathrm{~kg}, 2.97$ $\mathrm{kg}$ per $\mathrm{kg}$ gain, respectively). Differences were at 0.19 $\mathrm{kg}(\mathrm{Fl})$ and $0.03 \mathrm{~kg}$ per $\mathrm{kg}$ gain (FCR) between groups (table 2). These slight differences were not statistically significant ( $p>0.05)$.

\section{Meat quality}

Considering carcass elements, the analysis showed that the weight of offal was significantly lower $(p=0.038)$ in ducks from group 1 compared to group 2 (Table 3). Other post-slaughter parameters of ducks did not differ significantly $(p>0.05)$ between groups 1 and 2 . There were no differences ( $p>0.05)$ in the weight and proportion of muscles and subcutaneous and abdominal fat in duck carcasses (Table 4). Physicochemical analysis of breast muscles revealed that duck breast muscles from group 2 were darker (higher value of $\left.L^{*}\right)(p=0.011)$ and yellower $\left(b^{*}\right)$ $(p=0.001)$ (Table 5). Leg muscles from group 1 were characterised by significantly greater $(p=0.020)$ water holding capacity compared to group 2 (Table 6). 
Table 2 - Productivity parameters of all of ducks (means) after 8-week rearing period.*

\begin{tabular}{|c|c|c|c|c|}
\hline $\begin{array}{l}\text { Group } \\
n=100 \text { per group }\end{array}$ & $\begin{array}{c}1 \\
x \pm S D\end{array}$ & $\begin{array}{c}2 \\
x \pm S D\end{array}$ & SEM & P-value \\
\hline IBW (g) & $52.89 \pm 5.54$ & $53.45 \pm 4.94$ & 0.34 & 0.105 \\
\hline FBW (g) & $3080.20 \pm 7.82$ & $3117.90 \pm 10.20$ & 0.25 & 0.610 \\
\hline BWG (g/day) & $54.06 \pm 0.62$ & $54.72 \pm 0.24$ & 0.24 & 0.084 \\
\hline $\mathrm{FI}(\mathrm{kg})$ & $9.07 \pm 0.85$ & $9.26 \pm 0.82$ & 0.17 & 0.594 \\
\hline FCR (kg/kg gain) & $2.94 \pm 0.09$ & $2.97 \pm 0.09$ & 0.02 & 0.589 \\
\hline
\end{tabular}

*no statistically significantly differences were found

$\mathrm{n}$ - number of ducks in each group; IBW - initial body weight (g) FBW - final body weight (g); BWG - body weight gain (g/day) Fl - feed intake (kg); FCR - feed conversion ratio $(\mathrm{kg} / \mathrm{kg}$ gain);

1) control group - fed with feed based on soybean meal; ${ }^{2)}$ experimental group - fed with feed based on yellow lupin;

$\mathrm{x}$ - means; $\pm \mathrm{SD}$ - standard deviation; SEM - standard error of measurement; comparisons between groups 1 and 2 on a one-way analysis of variance (ANOVA). Mean values represented by two pens per group ( 1 group $=50$ birds $/ 2$ pens).

Table 3 - Post-slaughter parameters of 8-week-old ducks (means; \pm SD; SEM).

\begin{tabular}{|c|c|c|c|c|c|}
\hline \multicolumn{2}{|c|}{$\begin{array}{l}\text { Group } \\
n=10 \text { per group }\end{array}$} & $\begin{array}{c}1 \\
x \pm S D\end{array}$ & $\begin{array}{c}2 \\
x \pm S D\end{array}$ & SEM & $p$-value \\
\hline \multicolumn{2}{|c|}{ Pre-slaughter body weight (g) } & $3088.00 \pm 64.60$ & $3116.00 \pm 85.66$ & 16.82 & 0.420 \\
\hline \multicolumn{2}{|c|}{ Weight of carcass (g) } & $2151.18 \pm 40.95$ & $2199.62 \pm 80.88$ & 15.01 & 0.108 \\
\hline \multicolumn{2}{|c|}{ Dressing percentage (\%) } & $69.68 \pm 1.78$ & $70.59 \pm 1.53$ & 0.37 & 0.239 \\
\hline \multirow{4}{*}{ 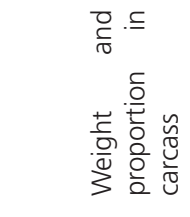 } & Neck with skin (g) & $268.97 \pm 26.52$ & $262.45 \pm 33.98$ & 6.68 & 0.638 \\
\hline & Neck with skin (\%) & $12.50 \pm 1.21$ & $11.93 \pm 1.54$ & 0.31 & 0.370 \\
\hline & Wings (g) & $290.13 \pm 26.12$ & $294.55 \pm 37.21$ & 7.01 & 0.762 \\
\hline & Wings (\%) & $13.49 \pm 1.21$ & $13.40 \pm 1.72$ & 0.32 & 0.898 \\
\hline \multicolumn{2}{|c|}{ Weight of offal (g) } & $145.38^{b} \pm 24.96$ & $166.24^{\mathrm{a}} \pm 15.67$ & 5.13 & 0.038 \\
\hline \multicolumn{2}{|c|}{ Carcass remains $(\mathrm{g})$} & $538.9 \pm 56.29$ & $544.38 \pm 66.77$ & 13.46 & 0.845 \\
\hline
\end{tabular}

a, b ....- means in columns marked with different letters differ significantly between groups, $p$-value $<0.05 ; n$ - number of ducks chosen to the carcass and meat analyses in each group; ${ }^{1)}$ control group - fed with feed based on soybean meal; ${ }^{2)}$ experimental group - fed with feed based on yellow lupin; $x$ - means; SD - standard deviation; SEM - standard error of measurement; comparisons between groups 1 and 2 on a one-way analysis of variance (ANOVA). Mean values represented by 10 birds per group ( 1 group $=5$ birds $/ 2$ pens).

Table 4 - Content of muscles and skin with fat in 8-week-old ducks (means; \pm SD; SEM).*

\begin{tabular}{|c|c|c|c|c|c|}
\hline \multirow{2}{*}{\multicolumn{2}{|c|}{$\begin{array}{l}\text { Group } \\
n=10 \text { per group }\end{array}$}} & & 2 & \multirow{2}{*}{ SEM } & \multirow{2}{*}{$p$-value } \\
\hline & & $\mathrm{x} \pm \mathrm{SD}$ & $\mathrm{x} \pm \mathrm{SD}$ & & \\
\hline \multirow{10}{*}{ 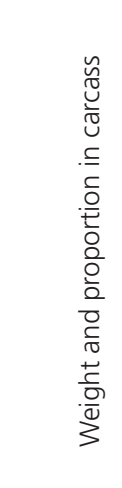 } & breast muscles (g) & $350.01 \pm 36.50$ & $354.94 \pm 54.98$ & 10.17 & 0.816 \\
\hline & Breast muscles (\%) & $16.27 \pm 1.67$ & $16.14 \pm 2.49$ & 0.46 & 0.892 \\
\hline & Legs muscles (g) & $246.52 \pm 53.54$ & $270.49 \pm 25.73$ & 9.55 & 0.218 \\
\hline & Leg muscles (\%) & $11.46 \pm 2.48$ & $12.30 \pm 1.06$ & 0.43 & 0.342 \\
\hline & Total muscles $(\mathrm{g})^{\#}$ & $596.53 \pm 79.46$ & $625.43 \pm 73.65$ & 17.00 & 0.410 \\
\hline & Total muscles $(\%)^{\#}$ & $27.73 \pm 3.68$ & $28.44 \pm 3.24$ & 0.76 & 0.656 \\
\hline & Skin with subcutaneous fat (g) & $537.00 \pm 88.36$ & $541.06 \pm 62.53$ & 16.67 & 0.907 \\
\hline & Skin with subcutaneous fat (\%) & $24.95 \pm 3.98$ & $24.59 \pm 2.57$ & 0.73 & 0.811 \\
\hline & Abdominal fat (g) & $25.44 \pm 12.57$ & $31.44 \pm 14.16$ & 2.99 & 0.330 \\
\hline & Abdominal fat (\%) & $1.18 \pm 0.57$ & $1.42 \pm 0.60$ & 0.13 & 0.373 \\
\hline
\end{tabular}

${ }^{*}$ no significant differences; $n$ - number of ducks chosen to the carcass and meat analyses in each group; ${ }^{1)}$ control group - fed with feed based on soybean meal; ${ }^{2)}$ experimental group - fed with feed based on yellow lupin; "total muscles = breast muscles + leg muscles; $\mathrm{X}$ - means; \pm SD - standard deviation; SEM - standard error of the mean; comparisons between groups 1 and 2 on a one-way analysis of variance (ANOVA). Mean values represented by 10 birds per group ( 1 group = 5 birds $/ 2$ pens). 
Table 5 - Physicochemical parameters of breast muscles from 8-week-old ducks (means; \pm SD; SEM).

\begin{tabular}{|c|c|c|c|c|c|}
\hline \multicolumn{2}{|l|}{$\begin{array}{l}\text { Group } \\
n=10 \text { per group }\end{array}$} & $\begin{array}{c}1 \\
x \pm S D\end{array}$ & $\begin{array}{c}2 \\
x \pm S D\end{array}$ & SEM & $p$-value \\
\hline $\mathrm{pH}_{15}$ & & $5.96 \pm 0.34$ & $5.94 \pm 0.18$ & 0.06 & 0.838 \\
\hline $\mathrm{pH}_{24}$ & & $5.97 \pm 0.17$ & $5.88 \pm 0.13$ & 0.03 & 0.219 \\
\hline \multirow{3}{*}{$\frac{\bar{े}}{0}$} & $L^{*}$ & $40.79^{b} \pm 2.65$ & $43.64^{a} \pm 1.77$ & 0.59 & 0.011 \\
\hline & $a^{*}$ & $11.25 \pm 1.47$ & $11.39 \pm 2.16$ & 0.40 & 0.864 \\
\hline & $b^{*}$ & $1.13^{b} \pm 0.96$ & $3.02^{\mathrm{a}} \pm 1.16$ & 0.32 & 0.001 \\
\hline WHC (\%) & & $36.03 \pm 5.14$ & $36.98 \pm 4.32$ & 1.04 & 0.659 \\
\hline Drip loss (\%) & & $1.18 \pm 0.60$ & $1.29 \pm 0.72$ & 0.15 & 0.711 \\
\hline
\end{tabular}

$a, b \quad \ldots-$ - means in columns marked with different letters differ significantly between groups, $p$-value $<0.05 ; n$ - number of ducks chosen to the carcass and meat analyses in each group; " ${ }^{1)}$ control group - fed with feed based on soybean meal; ${ }^{21}$ experimental group - fed with feed based on yellow lupin; WHC - water-holding capacity; $x$ - means; SD - standard deviation; SEM - standard error of the mean; comparisons between groups 1 and 2 on a one-way analysis of variance (ANOVA). Mean values represented by 10 birds per group (1 group $=5$ birds $/ 2$ pens).

Table 6 - Physicochemical parameters of leg muscles from 8-week-old ducks (means; \pm SD; SEM).

\begin{tabular}{|c|c|c|c|c|c|}
\hline $\begin{array}{l}\text { Group } \\
n=10 \text { per group }\end{array}$ & & $\begin{array}{c}1 \\
x \pm S D\end{array}$ & $\begin{array}{c}2 \\
x \pm S D\end{array}$ & SEM & $p$-value \\
\hline \multirow{3}{*}{$\frac{\grave{y}}{\mathrm{O}}$} & $L^{*}$ & $37.39 \pm 3.24$ & $40.22 \pm 4.06$ & 0.86 & 0.101 \\
\hline & $a^{*}$ & $10.10 \pm 3.31$ & $10.79 \pm 3.21$ & 0.71 & 0.641 \\
\hline & $b^{*}$ & $1.21 \pm 1.62$ & $1.10 \pm 0.37$ & 0.37 & 0.895 \\
\hline WHC (\%) & & $37.63^{b} \pm 6.08$ & $46.91^{\mathrm{a}} \pm 9.78$ & 2.07 & 0.020 \\
\hline
\end{tabular}

$\mathrm{a}, \mathrm{b} \ldots$...- means in columns marked with different letters differ significantly between groups, $p$-value $<0.05 ; n$ - number of ducks chosen to the carcass and meat analyses in each group; ${ }^{11}$ control group - fed with feed based on soybean meal; ${ }^{21}$ experimental group - fed with feed based on yellow lupin; $x$ - means; SD - standard deviation; WHC - water-holding capacity; SEM - standard error of the mean; comparisons between groups 1 and 2 on a one-way analysis of variance (ANOVA). Mean values represented by 10 birds per group (1 group $=5$ birds $/ 2$ pens).

\section{DISSCUSION}

Various authors (Volek \& Marounek, 2009; Zduńczyk et al., 2016; Zwoliński et al., 2017) have reported that lupins are a good source of protein, having a positive impact on productivity parameters in turkeys and rabbits. According to Smulikowska \& Rutkowski (2018) feed for waterfowl should contain 17.05\% of crude protein and $12.3 \mathrm{MJ}$ of metabolic energy per kg. Karasiński et al., (1988) provided ducks with feed containing different varieties of narrow-leaved lupin Lupinus angustifolius (bitter vs sweet; 30\%), and reported, unlike in our study, lower pre-slaughter body weight (at week 8) in ducks on a lupin-based diet. Similar experiments conducted by Olver (1997; 1998) revealed lower productivity of ducks fed with bitter lupin, which was attributed to the higher level of alkaloids in these plants. Similar results to those obtained in our experiment were reported by Mihok (1997), who used 13 to $20 \%$ of lupin in feed rations for Cherry valley ducks and found no significantly lower pre-slaughter body weight in 7-week-old birds.
In a similar experiment carried out by Rutkowski et al., (2004) the body weight of Pekin ducks reared for 8 weeks and fed with a concentrate containing legumes grown in Poland was $311 \mathrm{~g}$ higher compared to ducks on a diet containing soybean meal. The cited authors also concluded that the feed conversion ratio (FCR) was slightly lower in the group of ducks receiving a concentrate with legumes compared to the group on a conventional diet ( $F C R=3.45$ vs $F C R=3.61$ ). However, these FCR values were higher than in our experiment (2.94 to 2.97).

In other studies, Adamski et al., (2011) and Kowalczyk et al., (2012) analysed the carcass composition and meat characteristics of Pekin ducks receiving feed with maize distiller's dried grains with solubles (DGGS) as a source of protein in proportions of 15,25 and $30 \%$ per feed ration. Unlike in our study, Kowalczyk et al., (2012) reported that different diets influenced the weight of gutted carcass from 8-weekold ducks, which was highest $(2333 \mathrm{~g})$ in birds fed with 25\% DGGS, and lowest in birds fed with 30\% DGGS (2034 g). Nevertheless, like our experiment, 
these researchers found no effect of different diets on the dressing percentage and proportion of breast and leg muscles in the carcass. Their experiment revealed a lower proportion of breast muscles and a higher proportion of leg muscles compared to our study. As in our experiment, the above-mentioned researchers found no significant effect of different levels of DGGS as a source of protein in duck feed rations on the proportion of skin with subcutaneous fat, which was much higher than in Cherry Valley ducks.

We also found no effect of different diets on the $\mathrm{pH}$ of meat, water holding capacity, and drip loss from breast muscles. Similar conclusions were reached by Adamski et al., (2011), who reported that different diets (different levels of DGGS per feed ration) had no significant influence on $\mathrm{pH} 15$ and $\mathrm{pH} 24$ of breast muscles from 7-week-old Pekin ducks, but values of $\mathrm{pH}$ for breast muscles in their experiment were lower than in our study. Moreover, Adamski et al., (2011) found no significant differences $(p>0.05)$ between nutritional groups in terms of water-holding capacity, as well as lightness $\left(L^{*}\right)$, redness $\left(a^{*}\right)$ and yellowness $\left(b^{*}\right)$ of breast muscles. Of note is that the values of all parameters of breast muscle colour in the cited experiment were generally higher than in our study. Different diets (yellow lupin vs soybean meal) had no influence $(p>0.05)$ on the colour of duck breast muscles in a study by Witak et al., (2006). A significantly higher lightness $\left(L^{*}\right)$ and higher yellowness $\left(b^{*}\right)$ of the breast muscles may indicate a higher intramuscular fat content in the breast muscles (Zhao et al., 2017).

The addition of $38 \%$ yellow lupin to duck feed as a component rich in protein did not deteriorate most meat traits in birds, or the physicochemical parameters of their muscles. In conclusion, yellow lupin can be used as a partial protein source in feed rations to replace soybean meal in duck diet. These results showed that the use of alternative protein sources for soybean meal could help for small-scale producers of poultry rearing, with own crop resources. Other practical tests should be provided. It could be a sign for the producers, especially from traditional family farms, that we have a wider choice to do the production which obtain the good quality of poultry meat.

\section{ACKNOWLEDGEMENT}

The study was carried out under measure 4.4 "Qualitative assessment of animal raw materials produced based on domestic sources of vegetable protein" of the Multiannual Programme "Increased use of domestic feed protein to produce high-quality animal products under the conditions of sustainable development" [Resolution No. 222/2015].

\section{REFERENCES}

Adamski MP, Kowalczyk M, Łukaszewicz ET, Korzeniowska M. Effect of sex and inclusion of dried distillers' grains with solubles on slaughter yield and meat characteristics of Pekin ducks. British Poultry Science 2011;52(6):742-749.

Ali MS, Yang HS, Jeong JY, Moon SH, Hwang YH, Park GB, Joo ST. Effect of chilling temperature of carcass on breast meat quality of duck. Poultry Science 2008;87:1860-1867.

Biesek J, Kuźniacka J, Banaszak J, Adamski J. The quality of carcass and meat from geese fed diets with or without soybean meal. Animals 2020;10(2):200

Biesiada-Drzazga B, Charuta A, Janocha A, Łęczycka A. Assessment of the slaughter value of ducks Beijing STAR 53 HY. Roczniki Naukowe Polskiego Towarzystwa Zootechnicznego 2011;7(4):109-116. (in Polish)

CIE. Colorimetry [publication CIE 15.2]. Vienna: Central Bureau of CIE; 1986.

Grau R, Hamm R. Eine einfache Methode zur Bestimmung der Wasserbindung in Fleisch. Fleischwirt 1952;4:295-297.

Hejdysz M, Kaczmarek S, Rogiewicz A, Rutkowski A. Influence of graded dietary levels of meals from three lupin species on the excreta dry matter, intestinal viscosity, excretion of total and free sialic acids, and intestinal morphology of broiler chickens. Animal Feed Science and Technology 2018;241:223-232.

Honikel KO. The waterbindingofmeat. Fleischwirtschaft 1987;67(9):10981102.

Jamroz D, Kubizna J. Some beneficial effects of legume antinutritive substances. Krmiva- Zagreb 2007;49(6):317-346.

Jamroz D, Kubizna J. Harmful substances in leguminous seeds - their negative and beneficial properties. Polish Journal of Veterniary Sciences. 2008;11(4): 389-404.

Kaczmarek SA, Hejdysz M, Kubiś M, Kasprowicz-Potocka M, Rutkowski A. The nutritional value of yellow lupin (Lupinus luteus L.) for broilers. Animal Feed Science and Technology 2016;222: 43-53.

Karasiński D, Bednarczyk M, Peretiakowicz M, Gulewicz M. The influence of alkaloids in seeds of Lupinusangustifoliuson the growth and some meat features of ducks. Bullettin of the Polish Academy of Science. Biological Sciences 1988;36(10-12):215-224.

Kokoszyński D, Wasilewski R, Stęczny K, Bernacki Z, Kaczmarek K, Saleh $M$, et al., Comparison of growth performance and meat traits in Pekin ducks from different genotypes. European Poultry Science 2015:79.

Kowalczyk A, Łukaszewicz E, Adamski M, Kuźniacka J. Carcass composition and meat characteristics of Pekin ducks in relations to age at slaughter and level of maize distiller's dried grains with solubles in diets. Journal of Animal and Feed Sciences 2012;21:157-167

Kuźniacka J, Adamski M, Czarnecki R, Banaszak M. Results of Rearing broiler chickens under various systems. The Journal of Agriculture Science 2014:6(4):19-25.

Kuźniacka J, Biesek J, Banaszak M, Rutkowski A, Kaczmarek S, Adamski $M$, et al., Effect of dietary protein sources substituting soybean meal on growth performance and meat quality in ducks. Animals 2020;10(1):133. 
Mazanowski A, Kisiel T, Gornowicz E. Carcass quality, meat traits and chemical composition of meat in ducks of paternal strains A44 and A55. Animal Science Papers and Reports 2003;21(4):251-263.

Mihok S. White lupine (Lupinus albus L.) in feed rations for meat ducks. Allattenyeszteses Takarmanyozas 1997;46(4):361-374.

Naveen Z, Naik BR, Subramanyam BV, Reddy PM. Studies on the quality of duck meat sausages during refrigeration. SpringerPlus 2016;5:20612075.

Nurkhoeriyati T, Huda N, Ahmad R. Physicochemical properties and sensory analysis of duck meatballs containing duck meat surimi-like material during frozen storage. Journal of Food Science 2012;71(1):591-598.

Olver MD. Effect of sweet lupins on duckling growth. British Poultry Science 1997;38:115-117.

Olver MD. Effect of sweet, bitter and soaked micronized bitter lupines on duckling performance. British Poultry Science 1998;39:622-626.

Rahman MM, Khan MJ, Chowdhury SD. Effect of feed supplementation on chemical composition of meat of three genotypes of scavenging ducklings in coastal areas of Bangladesh. Bangladesh Journal of Animal Science 2014;43(1):25-29.

Rutkowski A, Hejdysz M, Kaczmarek S, Adamski M, Nowaczewski S, Jamroz D. The effect of addition of yellow lupin seeds (Lupinus luteus L.) to laying hen diets on performance and egg quality parameters. Journal of Animal and Feed Sciences 2017;26: 247-256.

Rutkowski A, Hejdysz M, Kaczmarek S, Mikuła R, Kasprowicz-Potocka M, Zaworska A. Possibilities of using legumes in feeding monogastric animals. Warszawa: Fundacja Programów Pomocy dla Rolnictwa FAPA; 2004. (in Polish)

Smith DP, Northcutt JK, Qudsieh RI, Parisi MA. Effect of strain on duck breast meat quality. The Journal of Applied Poultry Research 2015;24(3):401407.

Smulikowska S., Rutkowski A. Nutritional recommendations and nutritional value of poultry feeds. cooperative work. $5^{\text {th }}$ ed. Adugodi: Institute of Physiology and Animal Nutrition; 2018.

Statistica PL. Version 10.0 [series 1101]. Cracow: StatSoft; 2011.

Świątkiewicz S, Arczewska-Włosek A, Józefiak D. The nutrition of poultry as a factor affecting litter quality and foot pad dermatitis - an updated review. Journal of Animal Physiology and Animal Nutrition 2017;101(5):e14-e20.
Volek Z, Marounek M. Whole white lupin (Lupinus albus cv. Amiga) seeds as a source of protein for growing-fattening rabbits. Animal Feed Science and Technology 2009;152:322-329.

Witak B, Górski J, Górska A. The effect of yellow lupine meal and extracted rapeseed meal on carcass composition and some characteristics of meat quality of 7-week-old ducks of strain A44. Proceedings of the $12^{\text {th }}$ European Poultry Conference; Sept 20016; Verona. p.10-14.

Wołoszyn J, Haraf G, Okruszek A, Ksiąźkiewicz J. Evaluation of duck genotype effect on some breast muscle properties. European Poultry Science 2011a;75(1):49-55.

Wołoszyn J, Okruszek A, Orkusz A, Wereńska M, Ksiąźkieiwcz J, Grajeta H. Effect of duck genotype on leg muscle properties. Archiv fur Tierzucht 2011b;54(6):649-660

Zdanowska-Sąsiadek Ż, Michalczuk M, Marcinkowska-Lesiak M, Damaziak $K$. Factors shaping the sensory characteristics of poultry meat. Bromatologia i Chemia Toksykologiczna 2013;46(3):344-353. (in Polish)

Zduńczyk Z, Krawczyk M, Mikulski D, Jankowski J, Przybylska-Gornowicz $B$, Juskiewicz J. Beneficial effects of increasing dietary levels of yellow lupine (Lupinus luteus) seed meal on productivity parameters and gastrointestinal tract physiology in eight-week-old turkeys. Animal Feed Science and Technology 2016;211:189-198.

Zhao $X$, Ren W, Siegel PB, Li J, Wang Y, Yin $H$, et al., Meat quality characteristics of chickens as influenced by housing system, sex and genetic line interactions. Italian Journal of Animal Science $2017 ; 17(2): 462-468$

Ziołecki J, Doruchowski W. Methods for assessing slaughter value. Poznań: COBRD; 1989. (in Polish)

Zwoliński C, Gugołek A, Strychalski J, Kowalska D, Chwastowska-Siwiecka I, Konstantynowicz M. The effect of substitution of soybean meal with a mixture of rapeseed meal, white lupin grain, and pea grain on performance indicators, nutrient digestibility, and nitrogen retention in popielno white rabbits. The Journal of Applied Poultry Research 2017;45:570-576. 
